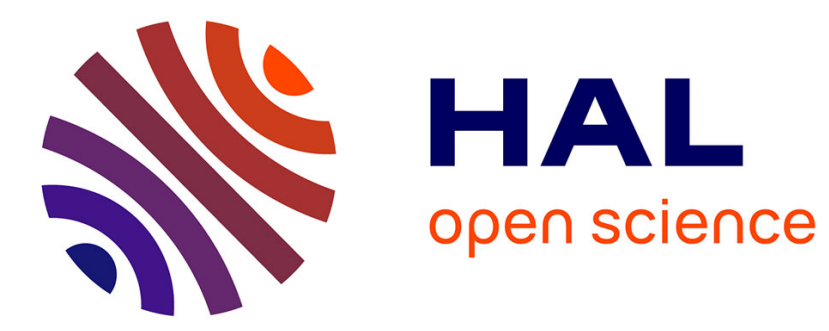

\title{
Biological control of mites in European vineyards and the impact of natural vegetation
}

Carlo Duso, Serge Kreiter, Marie-Stéphane Tixier, Alberto Pozzebon, Valeria Malagnini

\section{- To cite this version:}

Carlo Duso, Serge Kreiter, Marie-Stéphane Tixier, Alberto Pozzebon, Valeria Malagnini. Biological control of mites in European vineyards and the impact of natural vegetation. $\times 12$. International Congress of Acarology, Aug 2006, Amsterdam, Netherlands. 10.1007/978-90-481-9837-5_65 . hal01231310

\section{HAL Id: hal-01231310 https://hal.science/hal-01231310}

Submitted on 19 Nov 2015

HAL is a multi-disciplinary open access archive for the deposit and dissemination of scientific research documents, whether they are published or not. The documents may come from teaching and research institutions in France or abroad, or from public or private research centers.
L'archive ouverte pluridisciplinaire HAL, est destinée au dépôt et à la diffusion de documents scientifiques de niveau recherche, publiés ou non, émanant des établissements d'enseignement et de recherche français ou étrangers, des laboratoires publics ou privés. 


\title{
Biological control of mites in European vineyards and the impact of natural vegetation
}

\author{
Carlo Duso, Serge Kreiter ${ }^{1}$, Marie-Stéphane Tixier ${ }^{1}$, Alberto Pozzebon \& Valeria Malagnini2 \\ Department of Environmental Agronomy and Crop Science, University of Padova, Viale dell'Università, 16 - 35020 Legnaro \\ (PD), Italy. E-mail: carlo.duso@unipd.it; ${ }^{1}$ Montpellier SupAgro, UMR Centre de Biologie et de Gestion des Populations 1062 \\ INRA/IRD/CIRAD/SupAgro, Campus International de Baillarguet, CS 30 016, 34988 Montferrier sur Lez cedex, France; \\ 2FEM, via E. Mach, 138010 San Michele all'Adige (TN), Italy
}

\begin{abstract}
In vineyards, generalist phytoseiids are important in keeping phytophagous mites at economically acceptable levels. Among these predators, Typhlodromus pyri and Kampimodromus aberrans have proven to be most effective, because they increase in numbers in response to mite pests and alternative prey/food, they persist under conditions of prey scarcity, and they can tolerate several fungicides and insecticides. Natural colonization of commercial vineyards by phytoseiids may take several years. Therefore, strains showing field resistance to certain insecticides (e.g., organophosphates) and fungicides (e.g., mancozeb) are of practical interest. Here we report results obtained with releasing $T$. pyri and $K$. aberrans strains with different pesticide histories, with emphasis on factors affecting their persistence, i.e., alternative food availability (pollen or downy mildew), leaf morphology, and selective pesticides. Natural vegetation surrounding vineyards may impact the densities of phytoseiids in neighbouring crops. For example, phytoseiid densities on plants surrounding vineyards under IPM in Southern France (Languedoc-Roussillon) were correlated with leaf structures, and $K$. aberrans density appeared positively affected by high trichome densities and presence of domatia. Also pollen density was significantly correlated with trichome density and domatia (hair tufts). Predatory mites disperse mainly by air currents and hence their dispersion depends on wind intensity and direction. Crop colonization potential (speed, intensity, uniformity) was directly associated with phytoseiid densities and the proximity of natural vegetation. A deep, dense, and tall woody area with suitable host plants constitutes the stablest source of phytoseiids. Natural colonization of vineyards by phytoseiid mites has great potential and it may well be promoted by careful management.
\end{abstract}

Key words: Phytoseiids, Kampimodromus aberrans, dispersal, colonisation, woody areas, hedges, leaf morphology, pollen, fungi, IPM

$P^{\text {hatson }}$ hytophagous mites, tetranychids in particular, have been considered good examples of pests induced by the use of pesticides. This hypothesis also holds for mite pests on grape: tetranychid mites have a negligible impact in undisturbed ecosystems or in organic vineyards, but in commercial vineyards they become pests due to treatments with pesticides that harm their natural enemies. The spread of integrated pest management (IPM) in European viticulture in the 1980s and 1990s was associated with a decrease in the economic importance of tetranychids. In several parts of Europe the reduction in pesticide use, the selection of compounds that are relatively safe for beneficial arthropods, and the application of threshold levels for chemical control have increased the potential of natural enemies of tetranychid mites.

Whereas various predatory insects exert a significant role in suppressing mite outbreaks in vineyards, they are attracted mainly by rather high densities of tetranychid mites. Hence, their role in pest control is significant only when relatively high tetranychid threshold levels are applied (Duso \& Pasqualetto, 1993). Phytoseiidae in European vineyards are widely recognized as effective control agents, irrespective of the pest threshold level applied. A negative correlation between tetranychids and phytoseiids in the field was reported by the first researchers working on this topic (e.g., Mathys, 1958). The numerical response of phytoseiid mites to densities of tetranychid mites is often spectacular and, in contrast to insect predators, phytoseiids can persist under conditions of prey scarcity (Ivancich Gambaro, 1973; Girolami, 1981; Baillod et al., 1982).

\section{European vineyards are dominated by generalist phytoseiids}

In the last two decades faunistic surveys have been conducted on phytoseiids on grape in Europe. More than 20 species have been recorded in vineyards in Italy (Castagnoli, 1989;
Nicotina, 1996; Ragusa di Chiara \& Tsolakis, 2001) and France (Kreiter et al., 2000; Tixier et al., 2000b). Typhlodromus pyri Scheuten is the most common phytoseiid species on grapes in central Europe, Kampimodromus aberrans (Oudemans) is the most important in various southern regions, and Typhlodromus exhilaratus Ragusa plays a significant role in the Mediterranean viticulture. Other species frequently found are Amblyseius andersoni (Chant) and Phytoseius finitimus Ribaga. These species are considered to be generalists (type III, after McMurtry \& Croft, 1997), since they are characterised by their close association to host plants, a wide food range, and an intra-plant distribution wider than that of their prey. They can persist when prey densities decline by surviving on alternative foods, they can regulate their population densities, and compete successfully with other predators (McMurtry, 1992; McMurtry \& Croft, 1997). These features can be recognized at various levels in generalist phytoseiids encountered in European vineyards.

\section{Evaluating Amblyseius andersoni, Kampimodromus} aberrans, and Typhlodromus pyri in tetranychid control

Laboratory studies on food ranges have shown that $T$. pyri and $A$. andersoni develop and reproduce on tetranychids [e.g., Panonychus ulmi (Koch) and Eotetranychus carpini (Oudemans)], eriophyids [e.g., Colomerus vitis (Pagenstecher)], and pollen. Amblyseius andersoni exhibited shorter developmental times and higher oviposition rates than $T$. pyri, suggesting a higher intrinsic rate of increase (Duso \& Camporese, 1991). Kampimodromus aberrans showed a similar food range, and demographic parameters closer to T. pyri than to A. andersoni (Schausberger, 1992; Kasap, 2005; C Duso, unpubl.).

When released in experimental vineyards in north-eastern Italy, $T$. pyri and $K$. aberrans responded better to tetranychid population increases than $A$. andersoni (Duso, 1989). 
Additional observations showed that in some situations $A$. andersoni can control P. ulmi in vineyards (Vila et al., 1989; Camporese \& Duso, 1996), but confirmed its poor performance towards E. carpini (Duso \& Vettorazzo 1999). Kampimodromus aberrans proved to be the most effective phytoseiid in controlling E. carpini in various European regions (Ivancich Gambaro, 1973; Duso, 1989; Villaronga et al., 1991; Kreiter et al., 1993).

Amblyseius andersoni proved to be a key predator of $P$. ulmi in fruit orchards in northern Italy, south-west France, and other European regions, and its pesticide resistance contributed to this status (Ivancich Gambaro, 1986; S Kreiter, unpubl.). Its role in vineyards is certainly less important than in orchards: populations may crash suddenly despite pesticide resistance and resurge late in the season. This phenomenon is most likely due to this species' relative humidity requirements. Moreover, $A$. andersoni is less well able to persist in conditions of prey scarcity than $T$. pyri and especially $K$. aberrans. In northern Italy $K$. aberrans seems to have adapted better than T. pyri to harsh environmental factors such as high temperature, interspecific competition, and unfavourable leaf morphology (Duso \& Pasqualetto, 1993; Duso \& Vettorazzo, 1999). The ability of $K$. aberrans to outcompete $T$. pyri, observed repeatedly, is not due to higher predation rate (Schausberger, 1997), but probably to the smaller amount of food needed to survive (C Duso, unpubl.). In the laboratory, T. pyri exhibited a higher competitive ability towards K. aberrans (Schausberger, 1998), suggesting that these contrasting results may depend on differences between geographic races.

Typhlodromus pyri and $K$. aberrans reached higher population densities on cultivars having hairy leaf undersurfaces, whereas A. andersoni showed the opposite (Duso, 1992). This can affect colonisation patterns in vineyards comprising cultivars with different leaf morphology, as well as interspecific competition among phytoseiids (Camporese \& Duso, 1996; Duso \& Vettorazzo, 1999).

\section{Impact of Typhlodromus exhilaratus and Phytoseius finitimus on tetranychids in vineyards}

Typhlodromus exhilaratus is very common in central and southern Italy, Spain, southern France, and Greece (Castagnoli, 1989; Villaronga et al., 1991; Tixier et al., 2000b; Papaioannou-Souliotis et al., 1999). Its food range includes tetranychids, eriophyids, and pollen (Ragusa, 1979, 1981), and its intrinsic rate of increase is higher on E. carpini (and pollen) than on P. ulmi (Castagnoli \& Liguori, 1986a,b; Castagnoli et al., 1989). In field conditions, T. exhilaratus exhibits a rapid numerical response to $E$. carpini populations and this phenomenon is sometimes favoured by the presence of eriophyoids (Liguori, 1987, 1988). Typhlodromus exhilaratus easily adapts to conditions of low relative humidity, a fundamental factor for its persistence in vineyards of southern Europe (Liguori \& Guidi, 1995). The effectiveness of T. exhilaratus in controlling tetranychids has not been compared with that of other phytoseiids.

Phytoseius finitimus is another very common species in Italy, Greece, and other Mediterranean countries (Castagnoli, 1989; Nicotina, 1996, Papaioannou-Souliotis et al., 1999, Kreiter et al., 2000; Ragusa \& Tsolakis, 2001). Its food range has been poorly studied in relation with mites occurring on grapes, but it certainly includes tetranychids, eriophyoids, and pollen (Rasmy \& El-Banhawy, 1975). This species may have potential for controlling $P$. ulmi but seems to be ineffective towards E. carpini (Duso \& Vettorazzo, 1999). Phytoseius finitimus populations reach higher densities on hairy grape cultivars, which may affect interspecific competition (Duso \& Vettorazzo, 1999).

\section{Role of alternative prey for generalist phytoseiids}

The importance of alternative prey for phytoseiids has been widely debated in relation to the control of tetranychids (Helle \& Sabelis, 1985). Generalist feeding habits are a fundamental requirement for the persistence of predatory mites and for the success of biological control. Generalist phytoseiids can prey upon tenuipalpids, eriophyoids, tydeids, winterschmidtiids, young stages of thrips, and coccids. These preys can support survival, development, or reproduction to various measures. However, it must be stressed that some of these phytophagous species can reach pest status. Low to moderate populations of Colomerus vitis (Pagenstecher) have no impact on grape yield, but the case of Calepitrimerus vitis (Nalepa) is different because this species can cause economic damage and is more risky to manage (Duso \& de Lillo, 1996). Some phytoseiid species have a higher fecundity on eriophyoids than on tetranychids (Lindquist et al., 1996). The occurrence of eriophyoids can increase the potential of generalist phytoseiids (such as $T$. pyri and $T$. exhilaratus) in responding to tetranychid population buildups (Liguori, 1987, 1988; Engel \& Onhesorge, 1994a,b).

The role of tydeids as alternative prey for phytoseiids has been emphasized for a long time since the contributions dealing with Galendromus occidentalis (Nesbitt) in California, USA (Flaherty \& Hoy, 1971). However, laboratory studies and field observations do not support this hypothesis for the most common generalist phytoseiids in European vineyards. Tydeids are the preferred prey of some species of the genus Paraseiulus, in particular P. talbii (Athias-Henriot), but these species are hardly considered key predators of phytophagous grape mites (Camporese \& Duso, 1995).

Interspecific predation among generalist phytoseiids has been widely investigated. Typhlodromus pyri and $K$. aberrans can prey upon immature or adult stages of con- or heterospecific phytoseiids. Since these species partly inhabit the same plants, their immature or adult stages can be regarded as potential prey for competitive phytoseiids under conditions of food scarcity (Schausberger, 1999a). Adult females of $T$. pyri and $K$. aberrans are able to discriminate between con- and heterospecific immatures and they prefer to prey upon heterospecifics when given the choice (Schausberger, 1999b). Croft et al. (1996) report data on interspecific competition between $A$. andersoni and T. pyri.

\section{Factors affecting the persistence of phytoseiids when prey} is scarce: windborne pollen and pathogenic fungi

It is well known that generalist phytoseiids can develop and reproduce on pollen, but the impact of pollen on phytoseiid populations in vineyards has only been studied at a small spatial and short temporal scale. Studies in Germany showed that $T$. pyri populations peaked following phases with large pollen availability on leaves (Engel \& Onhesorge, 1994b). Long-term studies in north-eastern Italy confirmed a similar relationships for T. pyri, K. aberrans and, to a lesser extent, A. andersoni (Duso et al., 1997; Malagnini et al. unpubl.). The latter studies showed that grape leaves are excellent pollen traps, and that pollen trends typically have three major phases: in spring (May-June) the leaves host much pollen (especially arboreal pollen, Poaceae, Vitis vinifera L.), 
used by overwintered females and the first generations of predatory mites; in early summer pollen densities decline due to drought and phytoseiid numbers also decline; in late summer, phytoseiid abundance may increase again, sustained by weed flowers (Poaceae, Plantaginaceae, Chenopodiaceae, etc.).

Grape pathogenic fungi can also play an important role as alternative foods for generalist phytoseiids. Grape downy mildew (GDM), Plasmopara viticola (Berk. \& Curtis ex. de Bary) Berlese \& De Toni, and grape powdery mildew (GPM), Uncinula necator (Schwein.), are the most important worldwide grape pathogens. Late-summer spread of GDM foliar symptoms has been associated with sudden population increases of $A$. andersoni and, to a lesser extent, $T$. pyri (Duso et al., 2003). This phenomenon has been observed repeatedly in northern Italy, and is partly explained by the ability to develop and reproduce when reared on GDM in the laboratory (Pozzebon \& Duso, 2008). Additional effects of GDM involve interspecific competition between $A$. andersoni and T. pyri: GDM provide advantage to $A$. andersoni over $T$. pyri. Further studies should be addressed on the impact of GDM availability on spider mite biological control by generalists (Pozzebon, 2006).

An interesting case of interactions between predators and prey mediated by GDM concerns the phytoseiid $P$. talbii and the tydeid Tydeus caudatus Dugès. The latter can develop and reproduce on eriophyoids (e.g., Col. vitis) or on GDM (M Lorenzon, unpubl.) and is the preferred prey for $P$. talbi (Camporese \& Duso, 1995). GDM positively affected tydeid populations and consequently the response by the tydeid predator, P. talbii. Whether GDM can improve the control of grape eriophyids by tydeids still needs to be shown (Duso et al., 2005).

The effects of GPM on generalist phytoseiids has been the subject of recent investigations. Reared on this food source, $A$. andersoni and T. pyri were able to develop from egg to adult, but did not reproduce, suggesting the role of supplementary food for GPM (Pozzebon et al., 2009). This would imply enhanced persistence of these species in vineyards infected by powdery mildew. Research on interactions between powdery mildew and phytoseiids is required for species adapted to the Mediterranean climate where this pathogen is more aggressive.

Several generalist phytoseiids can feed on leaf sap (McMurtry, 1992; Kreiter et al., 2002). This would partly explain the ability of $A$. andersoni and $T$. pyri to persist when prey are scarce, but the real impact of this phenomenon requires in-depth investigation.

\section{Effect of non-prey food on phytoseiid coexistence}

The effects of non-prey foods on generalist phytoseiids may be more or less pronounced depending on the mite species. In systems with multiple species present, a specific non-prey food can mediate interspecific competition. Laboratory studies showed that $T$. pyri females developed faster on pollen than on GDM mycelium and that they laid more eggs when fed on pollen than on GDM. No differences in developmental times of $A$. andersoni were seen when they were reared on pollen or on GDM, whereas differences in oviposition confirmed the higher performance on pollen than on GDM (Pozzebon et al., 2008). In the field, however, the impact of these non-prey foods on T. pyri and A. anderson was different. On leaves, $T$. pyri population densities were positively correlated with pollen densities. In contrast, a non-significant linear relation was observed between $T$. pyri densities and GDM leaf symptom extent. Amblyseius andersoni population densities appeared to be positively related to the level of GDM leaf symptoms but not to pollen densities. The coexistence of these predatory mites in the same vineyard seemed to be due to a distinct preference for two different non-prey foods, irrespective of the results emerging from laboratory data. The pollen used in the laboratory (Papaver rhoeas L.) may have had a higher impact on $A$. andersoni demographic parameters than the pollen occurring in the vineyard (especially Poaceae and Vitis vinifera L.). Moreover, windborne pollen found on leaves by $A$. andersoni could be of lower quality than that provided every 3-4 days in the laboratory. Also, $A$. andersoni may be less effective than $T$. pyri in extracting nutrients from deteriorating pollen.

\section{How can we manage alternative non-prey foods for generalist phytoseiids?}

The management of alternative non-prey foods for generalist phytoseiids is crucial for the progress of biological control in vineyards. Some arboreal plants can provide large amounts of pollen. An interesting case of natural vegetation interacting with vineyards was observed on hilly areas close to the Italian Alps, where hop hornbeam (Ostrya carpinifolia L.) flowering was overlapping with grape sprouting. Large densities of hop hornbeam pollen were found on newly developed leaves colonized by overwintering females of $T$. pyri. Phytoseiid oviposition and the first generation were favoured by pollen abundance (Duso et al. unpubl.).

We also investigated the potential role of an experimental hedgerow in providing pollen (and phytoseiids) to a neighbouring vineyard. Among the plants included in these hedgerows, elderberry produced large amounts of pollen. Populations of the predatory mite Euseius finlandicus (Oudemans) increased on elderberry after flowering but the importance of this phenomenon for grapes was low in terms of pollen and predatory mites (Duso et al., 2004b).

The main component of windborne pollen in vineyards of northern Italy (and other European regions) comes from grasses (Poaceae). Nowadays, grasses are widely used as cover crops in vineyards. Field experiments showed that the amount of windborne pollen (mainly Poaceae) on the grape canopy can be increased by reducing the frequency of grass mowing. A moderate increase of phytoseiid densities was observed after this practice (Girolami et al. 2000, Malagnini et al. unpubl.).

The management of downy mildew is more complicated. GDM infections occurring in late summer are not economically important. In vineyards where $A$. andersoni is largely dominant, late-summer GDM infections could represent the most important factor for the persistence of this predator. However, it should be stressed that when A. andersoni and T. pyri coexist, the latter can be displaced by the former. Since $T$. pyri is more effective than $A$. andersoni in controlling tetranychids on grapes, infections by GDM could thus affect pest control by phytoseiids.

\section{Interactions between pesticides and phytoseiids in vineyards}

Pesticides applied in controlling grape pests and diseases can exert pronounced effects on phytoseiid survival, development, and reproduction, and may alter their response to the ecological factors mentioned above. The role of $T$. pyri in 
European viticulture has almost certainly been overestimated, probably because organophosphate (OP) resistance appeared first in this species (Baillod et al., 1982; Maixner, 1990; Vidal \& Kreiter, 1995). At the same time, A. andersoni has been considered an important bio-control agent of tetranychids in vineyards due to its high resistance to OPs and EBDC (Ethylenebisdithiocarbamate) fungicides (Duso et al., 1992; Angeli \& loriatti, 1994). Taking the latter factor as a priority, an OP resistant strain of $A$. andersoni was released in France and Switzerland in the 1980s (Caccia et al., 1985; Vila et al., 1989). However, this approach appeared to be unsuccessful.

The role of $K$. aberrans in European vineyards has been neglected, probably because resistance developed later than for other species (Corino, 1989; Marchesini \& Ivancich Gambaro, 1989). The spread of K. aberrans in some regions of Italy and France is most likely due to the recent appearance of strains able to survive repeated applications of EBDC (mainly mancozeb) and OPs (Vettorello \& Girolami, 1992; Posenato, 1994; Auger et al., 2004b).

Little is known about pesticide resistance in T. exhilaratus and Ph. finitimus. Their spread in commercial vineyards suggests that they can tolerate common pesticides.

\section{Should we release phytoseiids in vineyards?}

The natural colonization of phytoseiids can require several years, and can be favoured when natural vegetation is contiguous to vineyards. Phytoseiid strains occurring on natural vegetation are more susceptible to pesticides than those existing in vineyards and their settlement has a lower success rate if certain pesticides are used (Tixier et al., 1998, 2000a). Therefore, the interest for strains showing field resistance to several insecticides (e.g., OPs) and fungicides (e.g., mancozeb) has increased. Various strains of $T$. pyri and $K$. aberrans, most of them OP-resistant, were released in north-Italian commercial vineyards. The spread of grape yellows in the 1990s resulted in an increase of pesticide use; consequently, susceptible strains were able to persist in organic farms only. A strain of $K$. aberrans, collected in a vineyard treated with EBDC fungicides and OPs, was released in several experimental vineyards seriously infested by $P$. ulmi. The $K$. aberrans strain proved to control $P$. ulmi effectively and persisted for 10 years, despite unfavourable climatic conditions and repeated use of the EBDC and OP pesticides (Facchin et al., unpubl.).
Negative implications of augmentative releases of phytoseiids (e.g., low genetic variability of released predators) are matter of discussion. This strategy is often preferred to natural colonization in some areas, but poor results have been obtained in others, without a clear explanation.

Surrounding natural vegetation as a source of phytoseiids for dispersal into crops

Corino (1989) from Italy, Kreiter \& Sentenac (1995) from France, and many other authors have reported an increase in phytoseiid densities in vineyards managed through integrated farming. This process has been named 'colonization' and involves the presence of relatively rich and varied surrounding vegetation from which natural enemies disperse towards cultivated areas. Few studies have actually dealt with the process of colonization, but the occurrence of phytoseiid mites in surrounding vegetation is well documented as it is considered to be a potential reservoir of phytoseiids for vineyards (e.g., Boller et al., 1988; Kreiter \& Sentenac, 1995; Tixier et al., 1998, 2000a; Duso et al., 2004a). In some cases, species frequently found on natural vegetation, such as T. pyri or K. aberrans, have been found to be dominant in neighbouring vineyards (Boller et al., 1988; Tixier et al., 1998).

In the Languedoc region of southern France, phytoseiids have been found in the surroundings of experimental grape fields: in woody areas, border hedges, and neighbouring grape fields, $K$. aberrans represented on average $75 \%$ of the phytoseiids present (Tixier et al., 1998, 2000a). Diversity and densities appeared to be correlated to floristic diversity and to the abundance of suitable plants for the development of K. aberrans. This floristic diversity is itself linked to the local physical (climatic and edaphic) conditions, to vegetational succession (equilibrium status vs. colonizing process), and to the history of land use by men, all of which affect plant communities. In soils with colonizing vegetation in abandoned and replanted lands, T. exhilaratus seems to be dominant, a pioneer or real crop-colonizing species (Tixier et al., 2005), whereas in vineyards at higher altitudes and on the border between Mediterranean and Oceanic climatic conditions, $T$. pyri seems to replace and perhaps displace $K$. aberrans (Barbar et al., 2005; Kreiter et al., 2006).

Both diversity and abundance are affected by plant composition, due to the close relationship between plant leaf characteristics (i.e., pilosity) and mite development, espe-

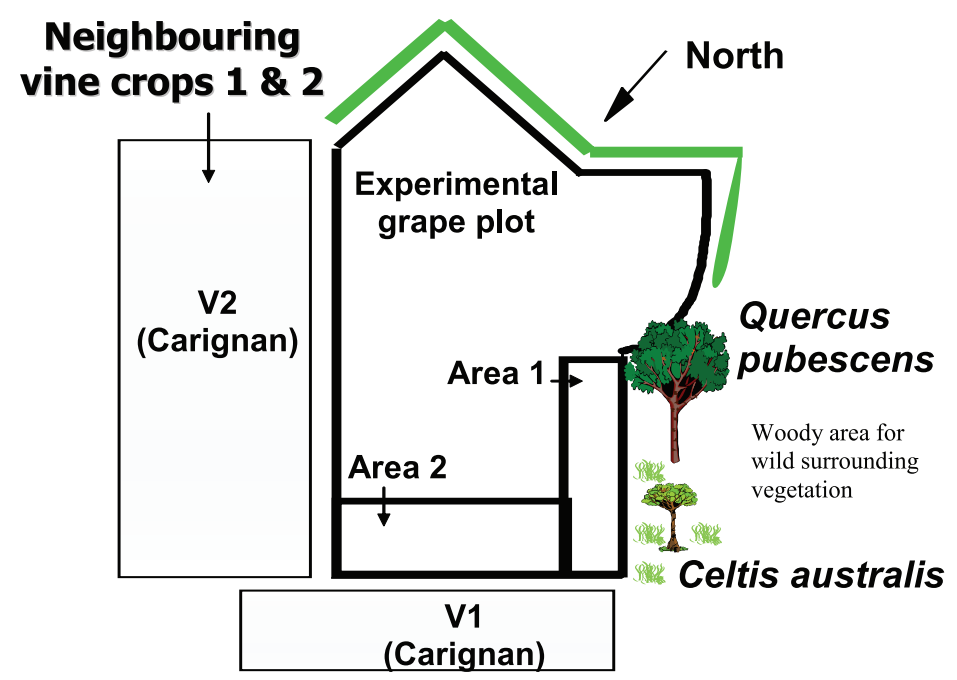

Figure 1 The experimental grape field (1) where colonisation was studied (Pouzolles, Languedoc, France). 
cially for K. aberrans (Tixier et al., 1998, 2000a; Kreiter et al. 2002). Higher trichome and domatia densities are correlated to higher predator densities. Trichome spacing of 160-180 um may allow $K$. aberrans to actively move in between trichomes, whereas larger predators cannot. Domatia ratings that reflect domatia complexity also seem to affect densities (Kreiter et al., 2002). Such leaf structures may allow habitat partitioning and more phytoseiid species to provide pest regulation at lower densities than single species (Croft \& Slone, 1998). Plants providing substrates, liquid, and pollen and whose leaves are characterised by pilosity and domatia, positively affect phytoseiids, especially generalist species (Karban et al., 1995; Walter, 1996; McMurtry \& Croft, 1997). For $K$. aberrans, these effects may also be present in one or more respects.

Finally, although several aspects of plant-phytoseiid interactions are described, not many aspects have been subjected to direct experimentation. Most of our conclusions are based on correlations or inferences from field-derived data. What is needed now are laboratory tests in simplified systems where variables can be controlled and single-factor relationships evaluated.

\section{Phytoseiid mite dispersal or the colonization processes of} plots

Phytoseiid mites disperse aerially and by ambulatory means (Sabelis \& Dicke, 1985). Their dispersal is thought to be motivated by the declining conditions of their habitats, i.e., overcrowding, poor quality food, abundance of predators, and yearly plant senescence (Price, 1984). Hamilton \& May (1977) developed a dispersal model and concluded that it was to the advantage of insects living in both stable and unstable environments that a portion of their offspring should disperse.

Our experiments showed that several phytoseiid species are liable to disperse in an aerial and/or ambulatory manner (Fig. 1; Tixier et al., 1998, 2000b, 2002a; Kreiter et al., 2006). This complies with previous observations on phytoseiid dispersal studied in the laboratory (Sabelis \& Dicke, 1985) and in the field (Hoy et al., 1985). Furthermore, aerial dispersal contributes to a greater extent than ambulatory dispersal (Tixier et al., 1998, 2000b; Kreiter et al., 2006). Fallen leaves and animal carriers (phoresy) can also transport phytoseiids, but this dispersal mode appears to be relatively insignificant (Kreiter \& Tixier, unpubl.). The number of dispersing mites and the number of those observed in cultivated fields increased together (Tixier et al., 1998, 2000b; Kreiter et al., 2006) (Fig. 2). However, this cannot be considered proof that dispersing phytoseiids effectively colonized the fields. Some species appear to disperse only by ambulatory displacement (soil or herbaceous stratum species according to Moraes et al., 1986), others only by aerial dispersal (tree inhabitants) (Moraes et al., 1986; Tixier et al., 1998, 2000b; Kreiter et al., 2006). However, K. aberrans, Typhlodromus intercalaris Livshitz \& Kuznetsov, and T. pyri have been trapped in both aerial and soil traps (Tixier et al., 1998, 2000b; Kreiter et al., 2006). After initiating aerial dispersal, these species might use ambulatory dispersal in order to reach a new plant.

Among the eight species trapped in the Languedoc, $K$. aberrans was the most abundant. Some data (Kreiter et al., unpubl.) revealed this species to have a low dispersal rate. An environment particularly rich in $K$. aberrans would be a source population for dispersal to poorer environments and the numbers of $K$. aberrans trapped could represent only a very small proportion of the populations present in the source area. Males and females have similar dispersal properties, both in the air and on land (Tixier et al., 1998, 2000b; Kreiter et al., 2006). Most of the literature available to date presents females, especially gravid ones, as being the most dispersive, but these results were obtained in laboratories and concerned type-I species (McMurtry \& Croft, 1997), which are biologically very different from types III and IV which are dominant in vineyards and orchards. Equally, a considerable number of immatures were found in the aerial traps in our experiments (Tixier et al., 1998, 2000b; Kreiter et al., 2006), which is also an uncommon result, especially for predator-types III and IV.

Soil and aerial trap catches support the view that phytoseiids disperse from woody areas and from not very far away (Fig. 3). Phytoseiid mite species were trapped between 30 and $90 \mathrm{~m}$ in experimental grape fields studied in the Languedoc (Fig. 3; Tixier et al., 1998, 2000b; Kreiter et al., 2006). Aerial movement might be adopted for long-distance dispersal, whereas ambulatory dispersal would be better adapted to shorter displacements. Kampimodromus aberrans was observed to disperse the farthest, whereas $T$. pyri and $T$. intercalaris were found mostly in traps located near the border of the woody area. This would confirm observations that $T$. pyri only disperses over short distances (Dunley \& Croft, 1992; Sentenac \& Valont, 1999).

Wind seems to be the main vector for aerial dispersal of phytoseiids and particularly of $K$. aberrans (Fig. 4). In our study, the N-NW winds, varying from 14 to $31 \mathrm{~km} / \mathrm{h}$ in speed, facilitated dispersal of phytoseiid mites (Tixier et al., 1998, 2000a; Kreiter et al., 2006).

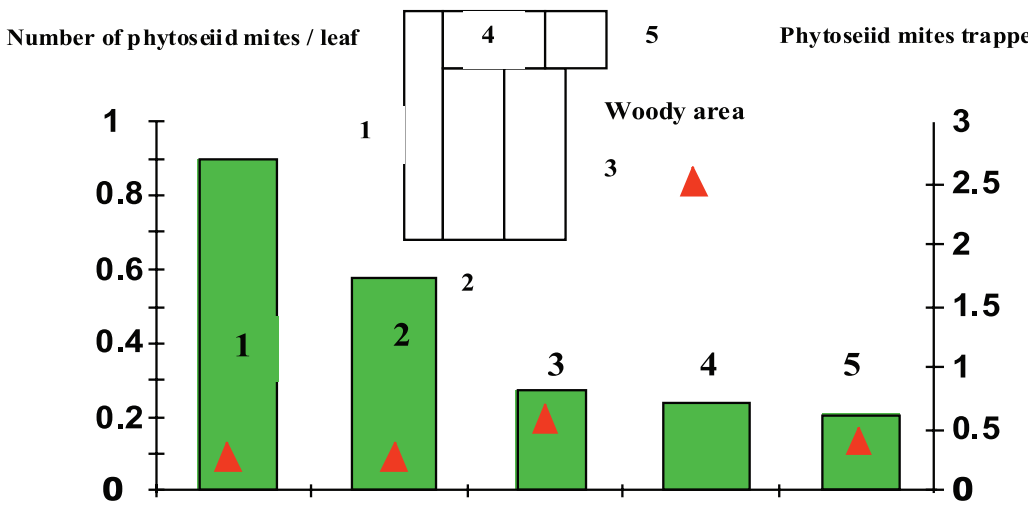

Various zones inside the experimental grape field 1 


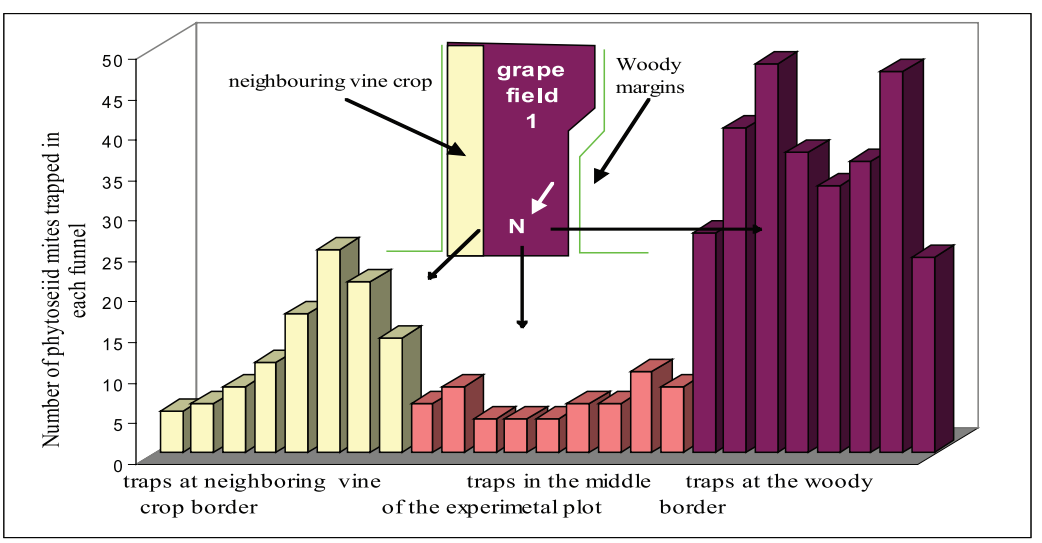

Figure 3 Number of phytoseiid mites trapped from 13 May to 01 October 1998 (>80\% Kampimodromus aberrans) and location of trapping within the experimental grape field 1 (Pouzolles, France; see Fig. 1).

\section{Relationship between Kampimodromus aberrans populations in vineyards and natural vegetation?}

To answer this question, a molecular typing (RAPD) of specimens collected in vine crops and in the neighbouring vegetation was carried out. The similarities between the genetic patterns of these mites were studied for two sampling dates, May and July. For both dates there was genetic similarity between females originating from Quercus pubescens Willdenow and those from Celtis australis L. (Tixier et al., 2002a,b). In a same way, the RAPD patterns of females from vineyards surrounding the experimental plot were also similar from each others. However, differentiation in genetic patterns was observed between mites collected in the experimental plot and mites observed in the surroundings (in woody margins and in neighbouring vine crops), irrespective of geographic distance (Tixier et al., 2002a,b) and despite the great number of migrants arriving in the experimental plot and certainly originated from the woody area (Tixier et al., 1998, 2000b). Such results may be explained by the low dispersal ability (distance or/and frequency) of $K$. aberrans (Fauvel \& Cotton, 1981; Perrot-Minnot, 1990; Tixier et al., 1998; Jung \& Croft, 2001) or to the highly aggregated distribution of this mite (Malison et al., 1995; Tixier et al., 2000b). Genetic distances among and between populations were lower in July than in May. Such genetic homogenisation is common for multivoltine organisms (De Barro et al., 1995). However, despite this homogenisation, we still observed differences between populations even after many $K$. aberrans individuals had dispersed into the experimental vineyard.

We expected that molecular typing would allow the identification of the source of $K$. aberrans; however, no strong correlations between genetic and geographic distances were observed.

These data describing weak relationships between mites from woody margins and nearby vine plots confirmed the population density trends observed by Tixier et al. (1998, 2000b; Kreiter et al., 2006). During a 3-year study, mite densities in some sites of the experimental plot did not increase even though high numbers of phytoseiids dispersed into this
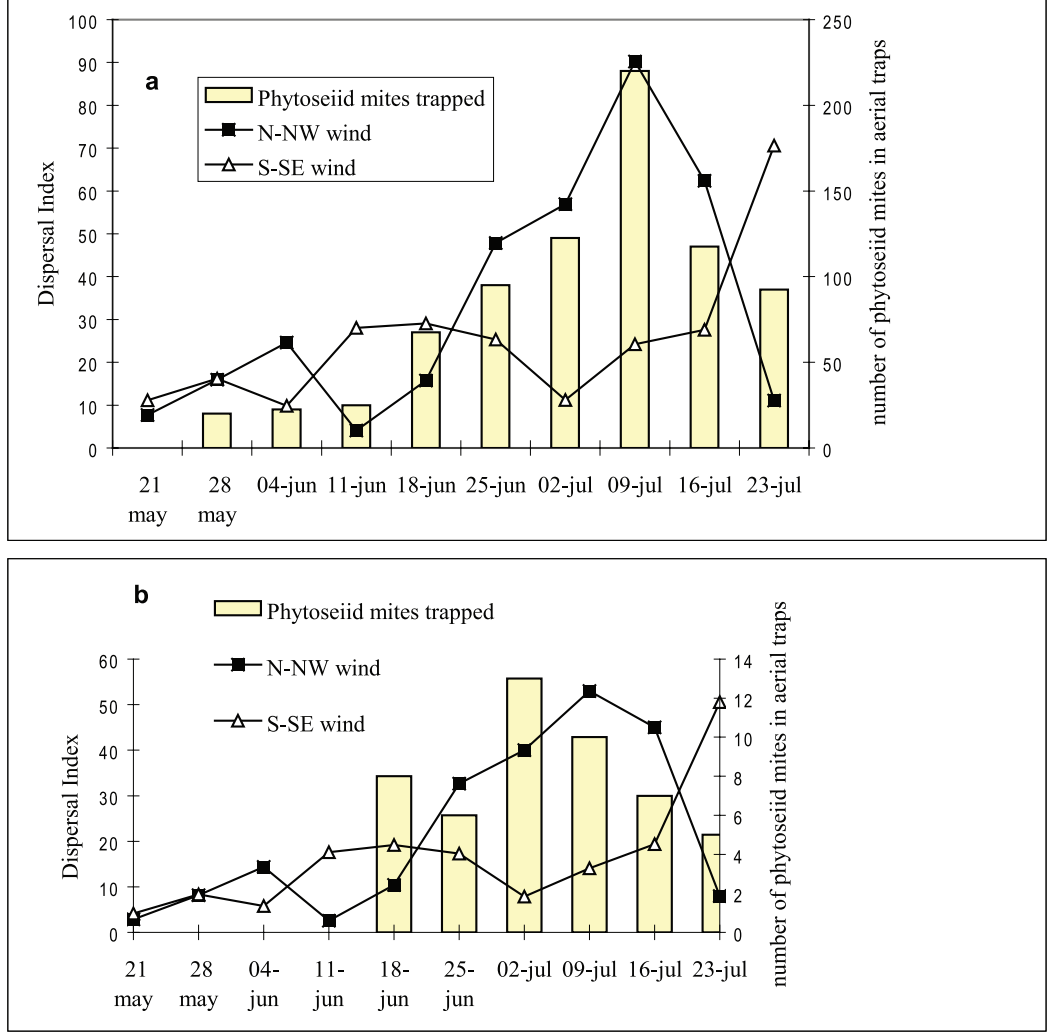

Figure 4 Correlations between total number of phytoseiid mites trapped in funnels full of water and a dispersal index for N-NW and S-SE major wind directions in experimental grape field 1 (A) and 2 (B) (Pouzolles, France; see Fig. 1). $r^{2}(N-N W$ wind $)=0.81$ and 0.48 , and $r^{2}(S-S E$ wind $)=0.04$ and 0.02 , for experimental grape fields 1 and 2, respectively. Dispersal index $=$ number of days of wind from S-SE or N-NW $\times$ weekly mean wind velocity $\times$ richness of surrounding vegetation in phytoseiid mites / leaf. 
area. Apparently, not all immigrants settled and colonised. The results of our studies suggest that little gene flow occurs between experimental and surrounding environments. Within-site selection factors may reduce the number of migrant phenotypes able to settle. Pesticide applications, for instance, could select for different phenotypes in vineyards vs. surrounding natural vegetation. The leaf characteristics of the vine variety could also select for specific phenotypes of $K$. aberrans (Kreiter et al., 2002). Populations of another natural enemy, Diaeretiella rapae McIntosh (Hymenoptera: Braconidae), collected on several plants located $<1 \mathrm{~km}$ from each other, were also very different (Vaughn \& Antolin, 1998). Given the close relationships between phytoseiids, especially K. aberrans, and their host plants (Kreiter et al., 2002), we suggest that population differentiation could be due to selection pressure arising from plant-related factors. Further experiments must be conducted in order to confirm this hypothesis.

If females from surrounding areas dispersed into the experimental vineyard, then it seems that only mites with specific phenotypes (and genotypes) succeeded in colonising it. Such conclusions are similar to those of Roderick (1992, 1996) considering the evolution of phenotypes during postcolonization. This study also suggests that selection limits colonization. The RAPD tests confirm the results obtained from earlier artificial releases of $K$. aberrans showing that released mites rarely settle well (Kreiter et al., 1993). These conclusions have implications for the biological control of mite pests and emphasize the importance to identify factors that may contribute to the settlement of $K$. aberrans and of phytoseiid mites in general.

\section{Is settlement of migrants within plots always achieved?}

The settlement of migrants may be a limiting factor for the colonisation process, confirming the results obtained when releases of $K$. aberrans were conducted (Kreiter et al., 1993). In order to explain this, the susceptibility of mites living in vineyards and in the surrounding natural vegetation towards a pesticide (quinalphos) was studied (Tixier \& Kreiter, 2003). Pesticide resistance was observed for the two populations tested. The population collected on oak in the woody margin and that from the experimental vineyard had resistance coefficients of 52 and 313, respectively, and their regression slopes were significantly different from that of the reference.

Even if quinalphos has been applied regularly only $3 \times$ a year since 1998, this short period has been sufficient to allow resistance selection and development. Selection is probably promoted by multiple pesticide applications per year, the mites' pseudo-arrhenotokous sex determination system, and the existence of several generations per year. This resistance could also explain the higher competitiveness of $K$. aberrans in cultivated areas in comparison with other phytoseiids dispersing into the plot. Furthermore, it was the first time that pesticide resistance was observed in populations living in an untreated environment outside cultivated plots. Pesticide drift could sufficiently affect neighbouring populations, to select resistant genotypes present in this neighbouring natural vegetation even if the resistance level is lower than that of the populations living in the experimental vine plots. Even if the $\mathrm{LC}_{50}$ of populations collected on vine and oak are different, high mortality was observed for both populations treated at the recommended concentration ( 87 and $70 \%$ for females collected on oak and vines, respectively). This toxicity is certainly lower in field condi- tions and seems to show that quinalphos applications do not appear to affect migrants dispersing from oak more than mites already present in the vine plot. Hence, quinalphos spraying is probably not the main reason that explain that migrants do not settle well in vine plots. However, other pesticides, especially fungicides, are also applied and these may affect mite population dynamics (cumulative effects).

Further studies are thus needed in order to identify the other factors involved in the poor success of migrant settlement, as pesticide sprayings do not seem to be the only factor involved. Could reproduction incompatibilities between migrants and individuals already present in the plot explain the low gene flow observed? Do host plant shifts during dispersal of phytoseiids affect settlement in the vineyards? Indeed, several studies with more specific predators [e.g., Neoseiulus fallacis (Garman) and Neoseiulus californicus (McGregor)] show that host plants can influence and delay settlement (Castagnoli et al., 1999; Lester et al., 2000). Finally, what about the survival of mites during dispersal? Answers to these questions are needed in order to enhance the use of phytoseiids naturally occurring in vineyard surroundings.

\section{REFERENCES}

Angeli G \& Ioriatti C (1994) Susceptibility of two strains of Amblyseius andersoni Chant (Acari: Phytoseiidae) to dithiocarbamate fungicides. Exp Appl Acarol 16: 669-679.

Auger P, Bonafos R \& Kreiter S (2004) Mancozeb resistance patterns among Kampimodromus aberrans and Typhlodromus pyri (Acari: Phytoseiidae) strains from French vineyards. Can Entomol 136: 663-673.

Barbar Z, Tixier M-S, Kreiter S \& Cheval B (2005) Diversity of Phytoseiid mites in uncultivated areas adjacent to vineyards: a case study in South of France. Acarologia 45(2-3): 145-154.

Baillod M, Schmid A, Guignard E et al. (1982) Lutte biologique contre I'acarien rouge en viticulture. II. Equilibres naturels, dynamique des populations et expériences de lâchers de typhlodromes. Rev Suisse Viticult Arboricult Horticult 14: 345-352.

Boller EF, Remund U \& Candolfi PM (1988) Hedges as a potential sources of Typhlodromus pyri, the most important predatory mite in vineyards of northern Switzerland. Entomophaga 33: 249-255.

Caccia R, Baillod M, Guignard E \& Kreiter S (1985) Introduction d'une souche de Amblyseius andersoni Chant (Acari; Phytoseiidae) résistant à l'azinphos, dans la lutte contre les acariens phytophages en viticulture. Rev Suisse Viticult Arboricult Horticult 17: 285-290.

Camporese P \& Duso C (1995) Life history and life table parameters of the predatory mite Typhlodromus talbii. Entomol Exp Appl 77: 149-157.

Camporese P \& Duso C (1996) Different colonization patterns of phytophagous and predatory mites (Acari: Tetranychidae, Phytoseiidae) on three grape varieties: a case study. Exp Appl Acarol 20: 1-22.

Castagnoli M (1989) Recent advances in knowledge of the mite fauna in the biocenoses of grapevine in Italy. Influence of Environmental Factors on the Control of Grape Pest, Diseases and Weeds (ed. by R Cavalloro), pp. 169-180. Balkema, Rotterdam, The netherlands.

Castagnoli M \& Liguori M (1986a) Tempi di sviluppo e ovideposizione di Typhlodromus exhilaratus Ragusa (Acarina: Phytoseiidae) allevati con vari tipi di cibo. Redia LXXIX: 361-368.

Castagnoli M \& Liguori M (1986b) Laboratory rearing and construction of a life table for Typhlodromus exhilaratus Ragusa (Acarina: Phytoseiidae). Redia LXXIX: 591-596.

Castagnoli M, Liguori M \& Simoni S (1999) Effect of two different host plants on biological features of Neoseiulus californicus (McGregor). Intern J Acarol 25: 145-149.

Castagnoli M, Amato F \& Monagheddu M (1989) Osservazioni biologiche a parametri demografici di Eotetranychus carpini (Oud.) 
(Acarina: Tetranychidae) e del suo predatore Typhlodromus exhilaratus Ragusa (Acarina: Phytoseiidae) in condizioni di laboratorio. Redia LXXII: 545-557.

Corino L (1989) Les acariens phytophages sur vigne en Italie: évolution des populations et équilibres naturels avec les acariens prédateurs. Annales ANPP 2: 116-123.

Croft BA \& Slone DH (1998) Perturbation of regulated apple mites: immigration and pesticide effects on outbreaks of Panonychus ulmi and associated mites (Acari: Tetranychidae, Eriophyidae, Phytoseiidae and Stigmaeidae). Environmental Entomology 27: 1548-1556

Croft BA, Kim SS \& Kim DI (1996) Intra- and interspecific predation by Metaseiulus occidentalis, Typhlodromus pyri, Neoseiulus fallacis and Amblyseius andersoni on different life stages: effects on survival, oviposition and activity. Exp Appl Acarol 20: 435-444.

De Barro PJ, Sherrat TN, Brookes CP et al. (1995) Spatial and temporal genetic variation in British field populations of the grain aphid Sitobion avenae (Hemiptera: Aphididae) studied using RAPD-PCR. Proc Roy Soc, Lond B 262: 321-327.

Dunley JE \& Croft BA (1992) Dispersal and gene flow of pesticide resistance traits in phytoseiid and tetranychid mites. Exp App Acarol14: 313-325.

Duso C (1989) Role of Amblyseius aberrans (Oud.), Typhlodromus pyri Scheuten and Amblyseius andersoni (Chant) in vineyards. I. The effects of single or mixed phytoseiid population releases on spider mite densities. J Appl Entomol 107: 474-492.

Duso C (1992) Role of predatory mites Amblyseius aberrans (Oudemans), Typhlodromus pyri Scheuten and Amblyseius andersoni (Chant) (Acari: Phytoseiidae) in vineyards. III. Influence of variety characteristics on the success of $A$. aberrans and T. pyri. J Appl Entomol 114: 455-462.

Duso C \& Camporese P (1991) Developmental times and oviposition rates of predatory mites Typhlodromus pyri and Amblyseius andersoni (Acari, Phytoseiidae) reared on different foods. Exp Appl Acarol 13: 117-128

Duso C \& Pasqualetto C (1993) Factors affecting the potential of phytoseiid mites (Acari: Phytoseiidae) as biocontrol agents in Northern-Italian vineyards. Exp Appl Acarol 17: 241-258.

Duso C \& Vettorazzo E (1999) Mite population dynamics on different grape varieties with or without phytoseiids released (Acari: Phytoseiidae). Exp Appl Acarol 23: 741-763.

Duso C, Camporese P \& van der Geest LPS (1992) Toxicity of a number of pesticides to strains of Typhlodromus pyri and Amblyseius andersoni (Acari: Phytoseiidae). Entomophaga 37: 363-372.

Duso C, Malagnini V \& Paganelli A (1997) Indagini preliminari sui rapporti tra pollini e Acari Fitoseidi. Allionia 35: 229-239.

Duso C, Fontana P \& Malagnini V (2004a) Diversity and abundance of phytoseiid mites (Acari: Phytoseiidae) in vineyards and the surrounding vegetation in northeastern Italy. Acarologia 44: 31-47.

Duso C, Pozzebon A, Capuzzo C et al. (2003) Grape downy mildew spread and mite seasonal abundance in vineyards: Evidence for the predatory mites Amblyseius andersoni and Typhlodromus pyri. Biol Contr 27: 229-241.

Duso C, Malagnini V, Paganelli A et al. (2004b) Pollen availability and phytoseiid abundance (Acari: Phytoseiidae) on natural and secondary hedgerows. BioControl 49: 397-415.

Duso C, Pozzebon A, Capuzzo C et al. (2005) Grape downy mildew spread and mite seasonal abundance in vineyards: effects on Tydeus caudatus and its predators. Biol Contr 32: 143-154.

Engel R \& Ohnesorge B (1994a) Die Rolle von Ersatznahrung und Mikroklima im System Typhlodromus pyri Scheuten (Acari, Phytoseiidae) - Panonychus ulmi Koch (Acari, Tetranychidae) auf Weinreben I. Untersuchungen im Labor. J Appl Entomol 118: 129-150.

Engel R \& Ohnesorge B (1994b) Die Rolle von Ersatznahrung und Mikroklima im System Typhlodromus pyri Scheuten (Acari, Phytoseiidae) - Panonychus ulmi Koch (Acari, Tetranychidae) auf Weinreben II. Freilandversuche. J Appl Entomol 118: 224-238.

Fauvel G \& Cotton D (1981) Evolution des populations de typhlodromes, Amblyseius aberrans essentiellement, dans une haie d'ormes et un verger de pommiers et observations de leur transport par le vent. Proc. 6e Journée Phytiatrie Phytopharmacie Circummediterranéennes (ed. by J Coste), pp. 471-479. Technic Offset Pub, France.
Flaherty DL \& Hoy MA. (1971) Biological control of Pacific mites and Willamette mites in San Joaquin Valley vineyards. Part III. Role of tydeid mites. Res Pop Ecol 13: 80-96.

Girolami V (1981) Danni, soglie di intervento, controllo degli acari della vite. Proceedings III Incontro su la Difesa Integrata della Vite, Latina, 3-4 Dicembre 1981, Regione Lazio, pp. 111-143.

Girolami V, Borrella E, Di Bernardo A \& Malagnini V (2000) Influenza positiva sui Fitoseidi della fioritura del cotico erboso. Informatore agrario LVI: 71-73 .

Hamilton WD \& May RM (1977) Dispersal in stable habitats. Nature 269: 578-581.

Helle W \& Sabelis MW (1985) Spider Mites. Their Biology, Natural Enemies and Control, Vol. 1B. Elsevier Science, Amsterdam, The Netherlands.

Hoy MA, Groot RJJ \& Van de Baan HE (1985) Influence of aerial dispersal on persistence and spread of pesticide resistant Metaseiulus occidentalis in California almond orchards. Exp Appl Acarol 37: 17-31.

Ivancich Gambaro P (1973) II ruolo del Typhlodromus aberrans Oudemans (Acarina Phytoseiidae) nel controllo biologico degli Acari fitofagi del Veronese. Bolletino Zoologia Agraria Bachicoltura 11: 151-165.

Ivancich Gambaro P (1986) An ecological study of Amblyseius andersoni Chant (Acarina: Phytoseiidae) in the climate of the Po valley (North Italy). Long term research on OP-resistant populations. Redia 69: 555-572.

Jung C \& Croft BA (2001) Aerial dispersal of phytoseiid mites (Acari: Phytoseiidae): estimating falling speed and dispersal distance of adult females. Oikos 94: 182-190.

Karban R, English-Loeb G, Walker MA \& Thaler J (1995) Abundance of phytoseiid mites on Vitis sp.: effects of leaf hairs, domatia, prey abundance and plant phylogeny. Exp Appl Acarol 19: 189-197.

Kasap I (2005) Life-history traits of the predaceous mite Kampimodromus aberrans (Oudemans) (Acarina: Phytoseiidae) on four different types of food. Biol Contr 35: 40-45.

Kreiter S, Tixier MS \& Barbar Z (2006) The importance of the vegetation surrounding the agrosystems on predatory mites associated to vineyards. Proceed. Intern. Conf. La difesa Integrata della vite dagli artropodi dannosi, Marsala (Italia), 10-11 ottobre 2005, pp. 97-147.

Kreiter S, Sentenac G, Weber M \& Valentin G (1993) Les Phytoseiidae des vignobles français. Synthèse de 8 années de recensement. Annales ANPP 2: 597-609.

Kreiter S, Tixier MS, Croft BA et al. (2002) Plants and leaf characteristics influencing the predaceous mite Kampimodromus aberrans (Acari: Phytoseiidae) in habitats surrounding vineyards. Environ Entomol 31: 648-660

Kreiter S, Tixier MS, Auger P et al. (2000) Phytoseiid mites of vineyards in France (Acari: Phytoseiidae). Acarologia XLI: 77-96.

Lester PJ, Thistlewood HMA \& Harmsen R (2000) Some effects of prerelease host-plant on the biological control of Panonychus ulmi by the predatory mite Amblyseius fallacis. Exp Appl Acarol 24: 19-33.

Liguori M (1987) Andamento delle popolazioni di Acari fitofagi e predatori in due vigneti del Chianti. Redia LXX: 141-150.

Liguori M (1988) Effetto di trattamenti antiparassitari diversi sulle popolazioni del fitoseide predatore Typhlodromus exhilaratus Ragusa e su quelle degli acari fitofagi in un vigneto del senese. Redia LXXI: 455-462.

Liguori M \& Guidi S (1995) Influence of different constant humidities and temperatures on eggs and larvae of a strain of Typhlodromus exhilaratus Ragusa (Acari Phytoseiidae). Redia LXXVIII: 321-329.

Lindquist EE, Sabelis MW \& Bruin J (1996) Eriophyoid Mites. Their Biology, Natural Enemies and Control. Elsevier Science, Amsterdam, The Netherlands.

Maixner M (1990) Untersuchungen zur Insektizidresistenz de Raubmilbe Typhlodromus pyri Scheuten (Acari: Phytoseiidae) an Reben des Weinbaugebiets Mosel-Saar-Ruwer. Mitt Biol Bundesanstalt Land-Forstwirtschaft 257: 1-118.

Malison M, Baldacci R, Posenato G \& Girolami V (1995) Frequency distribution of Kampimodromus aberrans (Oud.) (Acari: Phytoseiidae) in vineyards and optimization of the sampling methods. Frustula Entomologica 18: 153-168. 
Marchesini E \& Ivancich Gambaro P (1989) Indagini sui Fitoseidi nei vigneti della Valpolicella in rapporto ai programmi di difesa. Due specie a confronto: Amblyseius aberrans (Oud.) e Typhlodromus pyri Scheuten. Redia LXII: 609-621.

Mathys G (1958) The control of phytophagous mites in Swiss vineyards by Typhlodromus species. Proceedings of 10th International Congress of Entomology, pp. 607-610.

McMurtry JA (1992) Dynamics and potential impact of 'generalist' phytoseiids in agroecosystems and possibilities for establishment of exotic species. Exp Appl Acarol 14: 371-382.

McMurtry JA \& Croft BA (1997) Life-styles of phytoseiid mites and their roles in biological control. Annual Review of Entomology 42 291-321.

Moraes GJ de, McMurtry JA \& Denmark HA (1986) A catalog of the mite family Phytoseiidae: references to taxonomy, synonymy, distribution and habitat. EMBRAPA-ddt-pub., Brasilia, Brazil.

Nicotina M (1996) Phytoseiid mites associated with vines in vineyards of the Campania region. Acarology IX Proceedings (ed. by $\mathrm{R}$ Mitchell, DJ Horn, GR Needham \& WC Welbourn), ,pp. 237-240. Ohio Biological Survey, Columbus, OH, USA.

Papaioannou-Souliotis P, Markoyaiannaki-Printziou D, Rumbos I \& Adamopoulos I (1999) Phytoseiid mites associated with vine in various provinces of Greece: a contribution to faunistics and biogeography, with reference to eco-ethological aspects of Phytoseius finitimus (Ribaga) (Acari: Phytoseiidae). Acarologia 40: 113-125.

Perrot-Minnot MJ (1990) Etude comparative de trois populations de l'acarien prédateur Kampimodromus aberrans (Oudemans) (Acari: Phytoseiidae): caractérisation biochimique et hybridation. Mémoire de DEA, USTL Montpellier, France.

Posenato G (1994) Popolazioni di Amblyseius aberrans (Oud.) resistenti ad esteri fosforici e ditiocarbammati. Informatore agrario L: 41-43.

Pozzebon A (2006) Relazioni tra Acari predatori generalisti e funghi patogeni della vite. Aspetti ecologici ed applicativi. PhD Dissertation, University of Padova, Italy.

Pozzebon A, Duso C \& Malagnini V (2005) Predatory mite population dynamics in vineyards: the role of alternative foods. AFPP - $2 e$ Colloque International sur les acariens des cultures, Montpellier, 24-25 Octobre 2005, CD Rom, pp. 1-7.

Price P (1984) Insect Ecology, 2nd ed. Wiley, New York, NY, USA.

Ragusa S (1979) Laboratory studies on the food habits of the predacious mite Typhlodromus exhilaratus. Recent Advances in Acarology I (ed. by JG Rodriguez), pp. 485-490. Academic Press, London, UK.

Ragusa S (1981) Influence of different kinds of food substances on the developmental time in young stages of the predacious mite Typhlodromus exhilaratus Ragusa (Acarina: Phytoseiidae). Redia 64: 237-243.

Ragusa di Chiara S \& Tsolakis H (2001) Phytoseiid faunas of natural and agricultural ecosystems in Sicily. Acarology: Proceedings of the 10th International Congress (ed. by RB Halliday, DE Walter, HC Proctor, RA Norton \& MJ Colloff), pp. 522-529. CSIRO Publishing, Melbourne, Australia.

Rasmy AH \& El-Banhawy EM (1975) Biology and predatory efficiency of two phytoseiid mites as affected by long-term pollen feeding. Entomophaga 20: 93-95.

Roderick GK (1992) Post-colonization evolution of natural enemies. Selection Criteria and Ecological Consequences of Importing Natural Enemies (ed. by WC Kauffman JR Nechols), pp. 71-86. Thomas Say Publications in Entomology, Lanham, MD, USA.

Roderick GK (1996) Geographic structure of insect populations: gene flow, phylogeography and their uses. Annual Review of Entomology 41: 325-352.

Sabelis MW \& Dicke M (1985) Long range dispersal and searching behavior. Spider Mites. Their Biology, Natural Enemies and Control, Vol. 1B (ed. by W Helle \& MW Sabelis), pp. 141-160. Elsevier Science, Amsterdam, The Netherlands.

Schausberger P (1992) Vergleichende Untersuchungen über den Einfluß unterschiedlicher Nahrung auf die Präimaginalentwicklung und die Reproduktion von Amblyseius aberrans Oud. und Amblyseius finlandicus Oud. (Acarina, Phytoseiidae). J App Entomol 113: 476-486.
Schausberger P (1997) Inter- and intraspecific predation on immatures by adult females in Euseius finlandicus, Typhlodromus pyri and Kampimodromus aberrans (Acarina, Phytoseiidae). Exp Appl Acarol 21: 131-150.

Schausberger P (1998) Population growth and persistence when prey is diminishing in single-species and two-species systems of the predatory mites Euseius finlandicus, Typhlodromus pyri and Kampimodromus aberrans. Exp Appl Acarol 88: 275-286.

Schausberger $P$ (1999a) Juvenile survival and development in Euseius finlandicus, Typhlodromus pyri and Kampimodromus aberrans (Acari: Phytoseiidae) feeding on con- and heterospecific immatures. Exp Appl Acarol 23: 297-307.

Schausberger P (1999b) Predation preference of Typhlodromus pyri and Kampimodromus aberrans (Acari: Phytoseiidae) when offered con- and heterospecific immature life stages. Exp Appl Acarol 23: 389-398.

Sentenac G \& Valont J (1999) La colonisation des parcelles de vigne par les acariens prédateurs phytoseiidae 2. Bilan de trois années d'étude, résultats et perspectives en Bourgogne. Proc Fifth Int Conf Pests Agric, Montpellier, France, 7-9 December 1999, pp 385-395.

Tixier MS \& Kreiter S (2003) The dispersal of Kampimodromus aberrans between uncultivated areas and grape fields: does pesticide applications affect the settlement of migrants? Insect Sci Appl 23: 21-29.

Tixier MS, Kreiter S \& Auger P (2002a) How can molecular data contribute to the analysis of the colonization of vineyards by Kampimodromus aberrans. Acarid Phylogeny and Evolution; Adaptation in Mites and Ticks (ed. by F Bernini, R Nannelli, G Nuzzaci \& E de Lillo), pp 331-340. Kluwer Academic Publishers, Dordrecht, The Netherlands.

Tixier MS, Kreiter S, Auger P \& Weber M (1998) Colonization of Languedoc vineyards by phytoseiid mites (Acari: Phytoseiidae): influence of wind and crop environment. Exp Appl Acarol 22: $523-$ 542.

Tixier MS, Kreiter S, Croft BA \& Auger P (2000b) Colonisation of vineyards by phytoseiid mites: their dispersal patterns in plot and their fate. Exp Appl Acarol 24: 191-211.

Tixier MS, Kreiter S, Croft BA \& Auger P (2002b) Colonization of vineyards by Kampimodromus aberrans (Oudemans) (Acari: Phytoseiidae): dispersal from surrounding plants as indicated by random amplified polymorphism DNA typing. Agric For Entomol 4: 255-264.

Tixier MS, Kreiter S, Cheval B \& Perrotin B (2005) Les espèces de phytoséiides présentes dans les vignobles du Languedoc-Roussillon et les facteurs qui affectent leur densité et leur diversité. Progrès Agricole et Viticole 122: 463-467.

Tixier MS, Kreiter S, Auger P et al. (2000a) Phytoseiid mite species located in uncultivated areas surrounding vineyards in three French regions. Acarologia 41: 127-140.

Vaughn TT \& Antolin MF (1998) Population genetics of an opportunistic parasitoid in an agricultural landscape. Heredity 80: 152162.

Vettorello G \& Girolami V (1992) Popolazioni di Amblyseius aberrans (Oud.) tolleranti ai ditiocarbammati. Informatore agrario XLVIII: 111-112.

Vidal C \& Kreiter S (1995) Resistance to a range of insecticides in the predaceous mite Typhlodromus pyri (Acari: Phytoseiidae): inheritance and physiological mechanisms. J Econ Entomol 88: 10971105

Vila Y, Kreiter S \& Sarthou JP (1989) Lutte biologique contre les acariens phytophages à l'aide de Phytoséiides dans les vignobles de Fronton et de Gaillac en Midi-Pyrénées. Annales AFPP 2: 411 418.

Villaronga P, Marques J, Casanovas S \& Ferragut F (1991) Les acariens phytophages et prédateurs dans les vignobles de l'Alt Emporda (Girona-Espagne). Progrès Agricole et Viticole 108: 519523.

Walter DE (1996) Living on leaves: mites, tomenta and leaf domatia. Annual Review of Entomology 41: 101-114. 
